The British Prime Minister 


\section{Also by Anthony King}

The British General Election of 1964 (with David Butler)

The British General Election of 1966 (with David Butler)

Britain Says Yes: The 1975 Referendum on the Common Market

The New American Political System (editor)

Both Ends of the Avenue: The Presidency, the Executive Branch and Congress in the 1980 s (editor) 


\title{
The \\ British Prime Minister
}

\author{
SECOND EDITION
}

Edited by

Anthony King

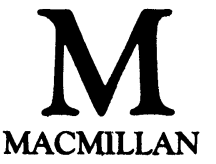


Editorial matter, selection and Chapter 4 (C) Anthony King 1985 Softcover reprint of the hardcover 2nd edition 1985

All rights reserved. No reproduction, copy or transmission of this publication may be made without written permission.

No paragraph of this publication may be reproduced, copied or transmitted save with written permission or in accordance with the provisions of the Copyright Act 1956 (as amended).

Any person who does any unauthorised act in relation to this publication may be liable to criminal prosecution and civil claims for damages.

First edition 1969

Reprinted 1974

Second edition 1985

Published by

Higher and Further Education Division

MACMILLAN PUBLISHERS LTD

Houndmills, Basingstoke, Hampshire RG21 2XS

and London

Companies and representatives

throughout the world

Typeset by

Wessex Typesetters Ltd

Frome, Somerset

British Library Cataloguing in Publication Data

The British Prime Minister.-2nd ed.

1. Great Britain. Prime Minister 2. Great

Britain-Politics and government-1979-

I. King, Anthony, 1934-

354.4103' 13 JN405

ISBN 978-0-333-38828-0

DOI 10.1007/978-1-349-17887-2 


\section{Contents}

Acknowledgements vii

Introduction: The Textbook Prime Ministership 1

1 A Prime Minister at Work Harold Wilson 12

2 The Conduct of Economic Policy 1974-79 Bernard Donoughue 47

3 The Prime Minister's Aides $\quad G$. W. Jones 72

The Prime Minister's Office under Margaret

Thatcher 1979-84

88

4 Margaret Thatcher: The Style of a Prime

Minister Anthony King

96

An Unusual Prime Minister

Three Premierships, Not One

Popular Responses

The Prime Minister as Leader

Respecting Power, Weighing It

People, Not Organisations

Presentation of Self, Uses of Self

Means to Ends: Match or Mismatch?

510 Downing Street Richard E. Neustadt

6 White House and Whitehall Richard E. Neustadt

155 


\section{Prime Ministerial Government}

R. H. S. Crossman $\quad 175$

The Effect of Party on the Individual MP 180

The Effect of Party on Control of the Executive 181

The Effect of Party on the Task of Opposition 181

The Effect of Party on the Struggle for Power 182

The Effect of Party on Ministerial Responsibility 183

The Reduced Role of Parliament 184

8 The Prime Minister's Power $\quad G . W$. Jones

9 The Case for a Constitutional Premiership

Tony Benn

The Argument in Outline 221

The Powers of the Party Leader in Opposition 225

The Powers of the Prime Minister in Office 228

Prime Ministerial Powers and Their Use 231

Towards a Constitutional Premiership

10 Strength at the Centre - The Case for a

\section{Prime Minister's Department Kenneth Berrill 242}

Bibliography 258

Index 


\section{Acknowledgements}

The author and publishers wish to thank the following who have kindly given permission for the use of copyright material:

The American Political Science Association and Professor Richard E. Neustadt for his article 'White House and Whitehall'.

Tony Benn for his lecture 'The Case for a Constitutional Premiership'.

Kenneth Berrill for his Stamp Memorial Lecture.

Andre Deutsch Limited for 'Richard E. Neustadt interviewed by Henry Brandon' extracted from Conversations with Henry Brandon.

Bernard Donoughue for his article 'The Conduct of Economic Policy 1974-79'.

Fontana Paperbacks for 'Prime Ministerial Government', part of R. H. S. Crossman's 'Introduction' to The English Constitution by Walter Bagehot.

G. W. Jones for 'The Prime Minister's Aides' published in Hull Papers in Politics, No. 6, University of Hull.

A. D. Peters \& Co. Ltd on behalf of G. W. Jones for his article 'The Prime Minister's Power' in Parliamentary Affairs, 1965, published by The Hansard Society.

Weidenfeld (Publishers) Limited and Michael Joseph Limited for extracts from The Governance of Britain, 1976, by Harold Wilson. 